\title{
Proceeding
}

Supplementary Issue: Summer Conferences of Sports Science. First International Conference in Iraq on Sport for Peace, 4 April 2019. Baghdad Science Institute, Baghdad, Iraq.

\section{The stakeholder's pressure and environmental supply chain: Does the environmental training matter in Thai sports manufacturing firms?}

\author{
SUDAWAN SOMJAI ${ }^{1}$, KOMKRIT RATTAMANEE 1 , KRITTAPOL THONGDONPUM ${ }^{1}$, KITTISAK \\ JERMSITTIPARSERT2,3 \\ ${ }^{1}$ Graduate School, Suan Sunandha Rajabhat University, Bangkok, Thailand \\ ${ }^{2}$ Department for Management of Science and Technology Development, Ton Duc Thang University, Ho Chi \\ Minh City, Vietnam \\ ${ }^{3}$ Faculty of Social Sciences and Humanities, Ton Duc Thang University, Ho Chi Minh City, Vietnam
}

\begin{abstract}
The main objective of the current study is to examine the impact of stakeholder's pressure on the environmental supply chain practices. Meanwhile, the mediating role of environmental training in the relationship between stakeholders' pressure and environmental supply chain is also examined. The study has used the SEM-PLS in the study. The data is collected from the operation and general managers of Thai sports firms. The response rate is 58.5 percent. The mediation analysis indicates a partial mediating role of environmental training in the relationship of regulatory stakeholders and market with the adoption of environmental supply chain practices. Two important findings are obtained in this study; firstly, regulatory governance and market stakeholders are of significant importance for implementing environmental supply chain practices. Secondly, greater environmental supply chain practices initiatives will be achieved by the use of environmental training, as compared to the case of separately using stakeholder governance mechanism as pressure for the firm. Findings also suggested that regulatory governance itself has an important role but combining it with market stakeholder may help firms to achieve effectiveness of sustainability enhancing initiatives. Keeping in view the essential role of environmental training programs, there is also a need to assess if these training programs play the role of mediator under different geographic and regulatory conditions and in other industries. In addition, no supportive evidence is obtained in favour of non-market stakeholders. The active role of non-market stakeholder in sustainability initiatives can also be examined in future studies. Keywords: Environmental; Supply chain; Stakeholders; Sports.

Cite this article as:

Somjai, S., Rattamanee, K., Thongdonpum, K., \& Jermsittiparsert, K. (2019). The stakeholder's pressure and environmental supply chain: Does the environmental training matter in Thai sports manufacturing firms? Journal of Human Sport and Exercise, 14(5proc), S2247-S2261. doi:https://doi.org/10.14198/ihse.2019.14.Proc5.42

Corresponding author. Department for Management of Science and Technology Development, Ton Duc Thang University, Ho Chi Minh City, Vietnam.

E-mail: kittisak.jermsittiparsert@tdtu.edu.vn

Supplementary Issue: Summer Conferences of Sports Science. First International Conference in Iraq on Sport for Peace, 4 April 2019. Baghdad Science Institute, Baghdad, Iraq.

JOURNAL OF HUMAN SPORT \& EXERCISE ISSN 1988-5202

(C) Faculty of Education. University of Alicante

doi:10.14198/jhse.2019.14.Proc5.42
\end{abstract}




\section{INTRODUCTION}

Stakeholders' pressure is assumed to be a significant and essential constituent of a firm's decision-making process and for the adoption of environmental management practices, since it is critical and urgent to achieve green sustainable economy (Tachizawa \& Wong, 2015). According to (Yawar \& Seuring ,2017), stakeholder pressure explains an organization's degree of accountability to which it is accountable for the decisions and actions about product designs, sourcing, its production and distribution. Several environmental scholars have acknowledged the environmental training's potential to adopt and integrate environmental SC practices (Liang \& Liu, 2017). Empirical findings suggest that training is a significant contributor of integrating environmental practices by a firm. For the comprehensive understanding of training and its effectiveness in the environmental supply chain management practices (ESCM) adoption requires further research (Epstein, 2018; Wong, Wong, \& Boon-Itt, 2015). Previous studies (Govindan et al, 2015; Hojnik \& Ruzzier, 2016; Mitra \& Datta, 2014) reported inconclusive findings for the relationship between ESCM adoption and stakeholder pressure. Since 1994, the Sports based manufacturers and exporters have been experiencing significant pressure both from the International regulatory authorities and foreign customers to enhance their product quality by imposing certain quality barriers to be followed while exporting to USA. In 1994, the Federal Drug Authority (FDA) banned the export of Sports instruments to the USA, due to failure to meet the International standards in terms of quality, such as, low quality of chromium content, hardness of stainless steel, and low metal composition quality. Although, a few large manufacturers became successful in obtaining sub-contracts from the new Southern African and Asian markets. After 1994 issue, an exclusive agreement was made between the Surgical Instrument Manufacturing Association (SIMA) and FDA, with an aim of providing required training to local producers regarding the up gradation of their standards of good manufacturing practices (GMP). These training are provided following the international standards and with the financial support of the government. The ESCM practices research has also gained popularity among the developed economies (Chin et al, 2015; Odeyale et al, 2014). However, with respect to Asian economies, only a limited empirical literature is available regarding the environmental practices adoption throughout the SC (Mitra \& Datta, 2014). The environmental sustainability mechanism and its drivers which stimulate and encourage firms to integrate environmental sustainability practices are still under-researched in the context of South Asia. According to (Jabbour \& Jabbour ,2016), ESCM practices involve green purchasing, eco-designs, internal environmental management, investment recovery, and cooperation with consumers. The Sports manufacturing industry is one of the leading industries in Thailand, with $6 \%$ of its trade contribution in the country's GDP. However, the relationship among environmental supply chain management (ESCM) adoption and pressures in Asia is still unclear and requires comprehensive research (Gupta \& Barua, 2017). In addition, there is little knowledge about the stakeholders' engagement for environmental management practices implementation (Meixell \& Luoma, 2015). The current research is conducted in response to (Betts et al, 2015) call for further research. For the hypothesis testing, resource-based view (RBV) and Stakeholder theory are applied. The stakeholder theory is applicable, since stakeholders tend to pressurize firms to adopt ESCM practices. Stakeholder theory is a well-recognized and widely used theory among researchers in the field of SCM (Betts et al., 2015; Liang \& Liu, 2017). According to (Bratton \& Gold ,2017), the resource-based view (RBV) demonstrates that if the firms possess knowledge and capabilities resources, then they are more likely to be inclined towards the implementation of ESCM practices. Resource base theory particularly emphasizes upon mediation analysis of environmental training (Esmaeilian et al, 2016). The present research is one of the early attempts of testing whether environmental training mediates the association among ESCM practices adoption and stakeholders' pressures to engage in environmental training for ESCM adoption in Asia. This research aims to analyse the role of environmental training as a mediator in the relationship of stakeholder pressures and environmental supply chain management practices adoption. The following research questions are addressed in this research: 
What are the major stakeholders in the environmental supply chain practices implementation?

Does environmental training acts as a mediator in relationship between GSCM practices adoption and stakeholder pressure?

\section{HYPOTHESES DEVELOPMENT}

Stakeholders are the major organizational actors which are central part of the firms' decision-making process (Stead \& Stead, 2017). Each stakeholder may have stakes in the performance of organization or holds a certain legitimate power to affect organizational performance, and also have different objectives, responsibilities and expectations towards firm (Tantalo \& Priem, 2016). The internal practices involve investment recovery and implementing environmental management programs, whereas, external practices involve cooperation with customers and green purchasing (Jabbour \& Jabbour, 2016; Liang \& Liu, 2017). Nonmarket stakeholders include government, media, business support groups etc. whereas the market stakeholders include customer, supplier and distributors (see figure 1).

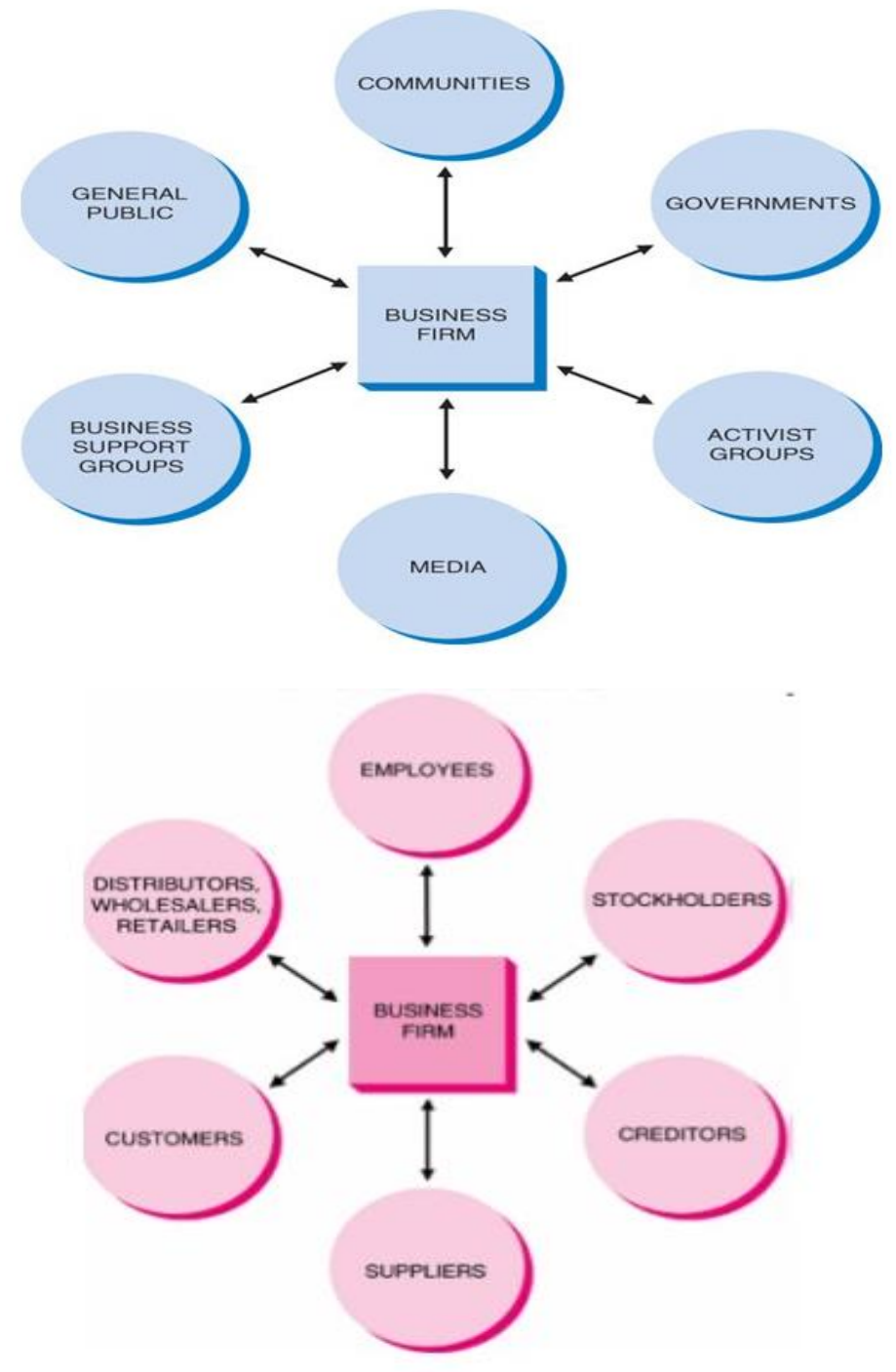

Figure 1. Market and Non-market stakeholders. 
External and internal green supply chain management definitions are used in this study following the definitions presented by (Jabbour \& Jabbour ,2016). GSCM and ESCM practices are have been interchangeably addressed and used in the academic researches (Hojnik \& Ruzzier, 2016; Jermsittiparsert et al, 2019; Jermsittiparsert et al, 2019). The study integrated stakeholder pressure as a key determinant in motivating firms to implement GSCM practices throughout the supply chain (Liang \& Liu, 2017). Several researchers have also suggested primary and secondary types of stakeholders, these include: consumer pressures, regulatory pressure, competitors, customer specific requirement, and investor and employees pressure (Liang \& Liu, 2017). (Meixell \& Luoma ,2015) suggested that market stakeholders (MRKTS) are capable of influencing the adoption of environmental practices through clients and customers pressures as compared to non- market stakeholders (NMRKTS), which include government regulations and public consciousness to spread awareness about environmental protection and green practices (Zhao \& Sun, 2016). Scholar view customers as the most important type of stakeholder. In addition, also suggested customers as an important driver having the ability to influence environmental strategy of a firm. In particular, international suppliers and export market are the major factors which create motivation among firms towards ESCM practices adoption. In view of different authors regulatory pressures and support are also essential factors for the firms to integrate GSCM practices. A study found suppliers, community, competitors, media, supply chain partners, and government regulations as the important stakeholders and drivers of ESCM practices adoption. (Liang \& Liu ,2017) have emphasized the positive association among GSCM practices adoption and stakeholder pressure and also suggested that the effective implementation of these practices can be facilitated through using environmental training programs. Furthermore, other studies (Jabbour \& Jabbour, 2016) also highlighted suppliers and customers as the key drivers. (Zhao \& Sun ,2016) found that adoption of GSCM practices is positively associated with community and domestic regulatory pressures. Moreover, the foreign supply chain partner plays an essential role in enhancing the life of citizens and also has the ability to influence firms by making them to follow international environmental standards. Primary and secondary stakeholder classification scheme is followed in this study. The primary or MRKTS are the ones which are directly associated with business activities. A conceptual model was proposed by (Wright \& Nyberg ,2017) which explains how non-market and MRKTS affect organizations. Therefore, we propose the following hypothesis:

H1: The MRKTS are in significant relationship with IENVCM.

H2: The NMRKTS are in significant relationship with IENVCM.

H3: The regulatory stakeholders are in significant relationship with IENVCM.

External environmental activities include sourcing renewable material, collaboration and cooperation with SC partners and customers. External environmental activities is referred as a firm's direct involvement with customers and suppliers for jointly planning the implementation of ESCM practices (Wong, Wong, \& Boonitt, 2018). The concept of green purchasing involve those activities which ensure certain environmental friendly characteristics, including reusable, no hazardous material and recyclable (Zhao \& Sun, 2016). A green selection criterion must be introduced for the suppliers in order to successfully implement GSCM practices in the firm's operations. According to (Zhao \& Sun ,2016) the term green purchasing referred to the environmentally-conscious purchasing activities which minimize waste or sources of waste and support reclamation and recycling the purchased items without causing any adverse impact on the performance of these items. In view of author, stakeholder pressure acts as an important driver and a determinant to which a firm has to comply (Zhao \& Sun, 2016). Besides, government pressures, competitive pressures, and customer environmental pressure are also found to be the important driving forces. A study by (Liang \& Liu ,2017) found supporting evidence for the idea that the greater the pressures from international suppliers and buyers on firm, the greater the susceptibility of implementing environmental friendly practices by firms in their operations. However, heterogeneous findings were reported in a study for its impact on the overall green SC. 
Revealed government, employees, NGOs, and customers as key drivers for adopting socially responsible activities. Foreign supply chain partners, government regulations, international environmental standards, domestic regulatory pressure, community, employees, special interest group, unions and regulations significantly influence the SCM practices adoption (Zhao \& Sun, 2016). (Wolf ,2014) investigated the relationship among supply chain management practices and stakeholders pressures and how this relationship influence the corporate sustainable performance. Furthermore, (Zhao \& Sun ,2016) argued that active cooperation of firms with customers occurs as a result of customer and regulatory pressures to implement green manufacturing and eco-design, respectively. However, government regulations play a significant role in integrating internal management practices, i.e. recycling and waste reduction practices (Odeyale et al., 2014). Majority of the South Asian firms consider environmental standards while making purchasing decisions, keeping into consideration the consumer pressure and international laws. The study proposes the following hypothesis, based on the aforementioned arguments:

H4: The MRKTS are in significant relationship with EENVCM.

H5: The NMRKTS are in significant relationship with EENVCM.

H6: The regulatory stakeholders are in significant relationship with EENVCM.

Training greatly emphasizes those approaches which aim to develop knowledgeable resources and skills and maintain these skills to ensure successful exchange of these resources (Liang \& Liu, 2017). At the initial stage of adopting environmental practices, internal orientation is required which claims that in-house environmental training depends upon the environmental orientation. Similarly, another study (Mohanty \& Prakash ,2014) also confirmed training as the most important factor in improving internal operations. Thus, a firm is required to develop certain employee capabilities, through training to integrate environmental related practices in its operations. It is also important to examine if training acts as a mediator in the relationship between green practices adoption and stakeholder pressure, however a same impact of these environmental practices is reported in other countries (Liang \& Liu, 2017). Empirical evidence found from (Paauwe \& Boon , 2018) study has shown that regulatory pressure is a significant driver for the employees to get training. Managers training also bring certain benefits to the organizations, such as increased efficiency of firms. Therefore, certain initiatives should be taken by the management towards initiating environmental training programs, particularly through knowledge building about material composition. According to (Jabbour \& Jabbour ,2016), industrial association's support plays a critical role in enhancing the firm's environmental management. (Liang \& Liu ,2017) reported a strong positive relationship in their study and found that training mediates this relationship and directly influence the eco-design. They also suggest training as a pre-requisite for the adoption of environmental management system. In addition, media is found to have no significant role in investing for those environmental training programs which assist firms in the adoption of environmental practices. In the operations management research, training appears to be a significant part of environmental management agenda, resulting from external pressures (Jabbour \& Jabbour, 2016). It has been argued that implementation of the environmental training programs arising as a result of pressures from different stakeholders to adopt ESCM practices does have a mediation impact on the stakeholder pressure and the adoption of GSCM practices relationship. Thus, it is hypothesized that:

H7: The MRKTS are in significant relationship with implementation of environmental training.

H8: The NMRKTS are in significant relationship implementation of environmental training.

H9: The regulatory stakeholders are in significant relationship with implementation of environmental training.

H10: Implementation of environmental training significantly mediates the relationship between MRKTS and IENVCM chain.

H11: Implementation of environmental training significantly mediates the relationship between MRKTS and EENVCM. 
H12: Implementation of environmental training significantly mediates the relationship between NMRKTS and IENVCM chain.

H13: Implementation of environmental training significantly mediates the relationship between NMRKTS and EENVCM.

H14: Implementation of environmental training significantly mediates the relationship between regulatory stakeholders and IENVCM chain.

H15: Implementation of environmental training significantly mediates the relationship between regulatory stakeholders and EENVCM.

\section{METHODOLOGY}

The population for current research is the exporting manufacturers from Sports, Thailand. Individual firm is taken as a unit of analysis in this study. Before starting the data collection process, pretesting is carried out by 20 managers from the ISO20183 manufacturing firms, to assess the completeness and readability of the survey (Loomis \& Paterson, 2018). Few items of the questionnaire were modified based on the suggestion from the manufacturers and following local industry standards. The study adopted a measurement scale from the already existing scales. The sampling frame for this study is developed from the list of registered exporters. Random samples were drawn from the exporters' list following the previous studies. Key respondents were drawn for the data collection from the organization. These knowledgeable respondents particularly from the production and operational departments were chosen to achieve the research objectives. From a total of 1100 manufacturing firms only 288 completed surveys were received from different industrial sectors, 16 questionnaires were excluded from the study because of incomplete information. Thus, $26 \%$ response rate is obtained with 272 useable questionnaires. These useable questionnaires were found to be consistent with the (Oraedu 2019) recommendation. The sample chosen for this study is above the minimum acceptable level and is $97 \%$ significant at $\alpha=0.05$. Similar response rate were reported in previous GSCM related studies (Govindan et al., 2015; Martens \& Carvalho, 2017). The sample composition is shown in Table1. The data for this study is collected from the targeted firms by adopting a key informant approach. Study chose those respondents who has export related experience with an average of 5 year working experience at middle or higher management position. This approach has also been adopted by a number of previous researches to obtain data both from the upper and middle level management and are consistent with the existing set of literature (Hojnik \& Ruzzier, 2016). Non-response bias test is performed to assess if there is any significant difference between response that is received earlier and the response that is received later.

\section{MEASUREMENT DEVELOPMENT}

A theoretical construct was adopted from the literature to test the proposed set of hypotheses. NMRKTS and market stakeholder constructs were extracted from (Juntunen et al, 2019), whereas regulatory stakeholder construct is adapted from (Miles ,2017) and (Bansal \& Song ,2017). To obtain survey responses, five-point Likert scale is used. The respondents were asked to rate the mediation level of environmental training in their firm and the degree to which it influences the GSCM practice adoption as a result of different stakeholders' influence. The 5 scales range from 1-5 where 1 represents not at all, 2 represents a little bit, 3 represents to some degree, 4 represents relatively strong, and 5 represents very strongly. According to (Juntunen et al. ,2019), MRKTS directly involves with the enterprise to make economic transactions and also significantly contributes to the value chain. The current study defined MRKTS as the ones who are in direct contact with firms and supply chain during economic transactions. Contrarily, NMRKTS referred to the ones having no direct involvement in economic transactions with firm, however, they do have significant impact on economic 
transactions. The questionnaire items for NMRKTS include mass media, government regulations, environmental pressure groups and non-governmental organizations. (Miles ,2017) argued that regulatory stakeholders possess the ability of influencing firm operations. The GSCM concept is based upon firm's environmental concepts and on firm's ability of managing SCM processes and its relationship with SCM life cycle (Wolf, 2014). The questionnaire items and scale for external and internal GSCM practices were adapted from study of (Jabbour \& Jabbour ,2016). The customers and suppliers ESCM activities were also observed from previous researches by (Wong et al. ,2018). The respondents were asked to rate the extent to which their firm has successfully adopted GSCM practices, using a 5-point Likert scale, where 1 represents not considering, 2 represents planning to consider, 3 represents considering it currently, 4 represents initiating implementation, and 5 represents fully implementing. Internal GSCM practices involve eco-design for process and product, integrating Environmental Management System (EMS), cross-functional collaboration to enhance environmental performance and source reduction (Jabbour \& Jabbour, 2016). Sourcing renewable material, integration and cooperation with SC partners are the external environmental activities. It also refers as those activities by firms to cooperate with customers and suppliers to plan for the adoption of GSCM practices (Wong et al., 2018). Environmental training is used in this study following the suggestions by (Liang \& Liu ,2017). In another question, respondents were asked to indicate the frequency of providing environmental training by your firm, where 1 represents frequently, 2 represents occasionally, 3 represents rarely, 4 represents very rarely, and 5 represents never.

\section{DATA ANALYSIS}

A combination of descriptive and inferential statistics was performed for data analysis. Descriptive analysis was performed by utilizing SPSS 22.0 which supply the overall understanding of the respondents' profile and demographic variables. Moreover, in descriptive statistics, the central tendency along with the variability of the data was 128 depicted and described to obtain further comprehension of the subject matter. Additionally, the inferential analysis was performed by using Partial Least Squares structural equation modelling by using Smart PLS 3.0 for making predictions from the data. To attain an adequate response rate, the researcher made several phone calls and follow up 132 visits to the selected firms. Subsequently, a total of 360 questionnaires were collected from nine public universities, giving a response rate of $60 \%$. A total of 9 questionnaires were excluded from analysis because of missing data and finally 351 useable questionnaires, with a response rate of $58.50 \%$, were examined for data analysis. This response rate is adequate according to (Dikko ,2016), he recommended that in survey research greater than 30 percent response rate is satisfactory. SEM is of two types and each type of SEM applies different estimation procedures, make different distributional assumptions and have different objectives. Originally developed by (Sarstedt \& Cheah ,2019), by using an ordinary least squares estimation method the aim of the PLS-SEM is maximization of change describes by the dependent variable. Previously, covariance-based structure. In the current study we have employed to be specific, the PLS technique because of several reasons. Firstly, PLS is a more effective approach/ technique when applied in complicated models with many manifest and latent variables. Second, PLS analysis don't have stringent criteria for the residual distribution and error term. Thirdly for the reflective and formative measurement models, the PLS path modelling can be used in (Henseler et al, 2015). Forth, PLS is able to explain the measurement error and give more accurate estimates of interaction effects like mediation/moderation. According to (Wong ,2016) for complex models the PLS is appropriate like the models with mediation and moderation effects as well as hierarchical constructs (with a complete disaggregation method). Lastly, PLS-SEM provide more valid and expressive results, whereas the other techniques give less lucid conclusions and would have need of performing 130 various separate analysis. Therefore, PLS path modelling was selected instead of CB-SEM to analyse the data in the present study. First of all, in PLS analysis, the measurement model was assessed to determine the relevance of indicators' loadings of 
particular constructs. Reliability test ascertains the consistency of the measurement instrument to measure the construct they were expected 139 to measure. Validity test examines the ability of a respective instrument to measure a construct that it purports to measure (Janadari et al, 2016). Moreover, the outer model also establishes the relationship between observable and latent constructs. Furthermore, estimation of content, discriminant and convergent validity of the instruments provide estimation for construct validity (CV).

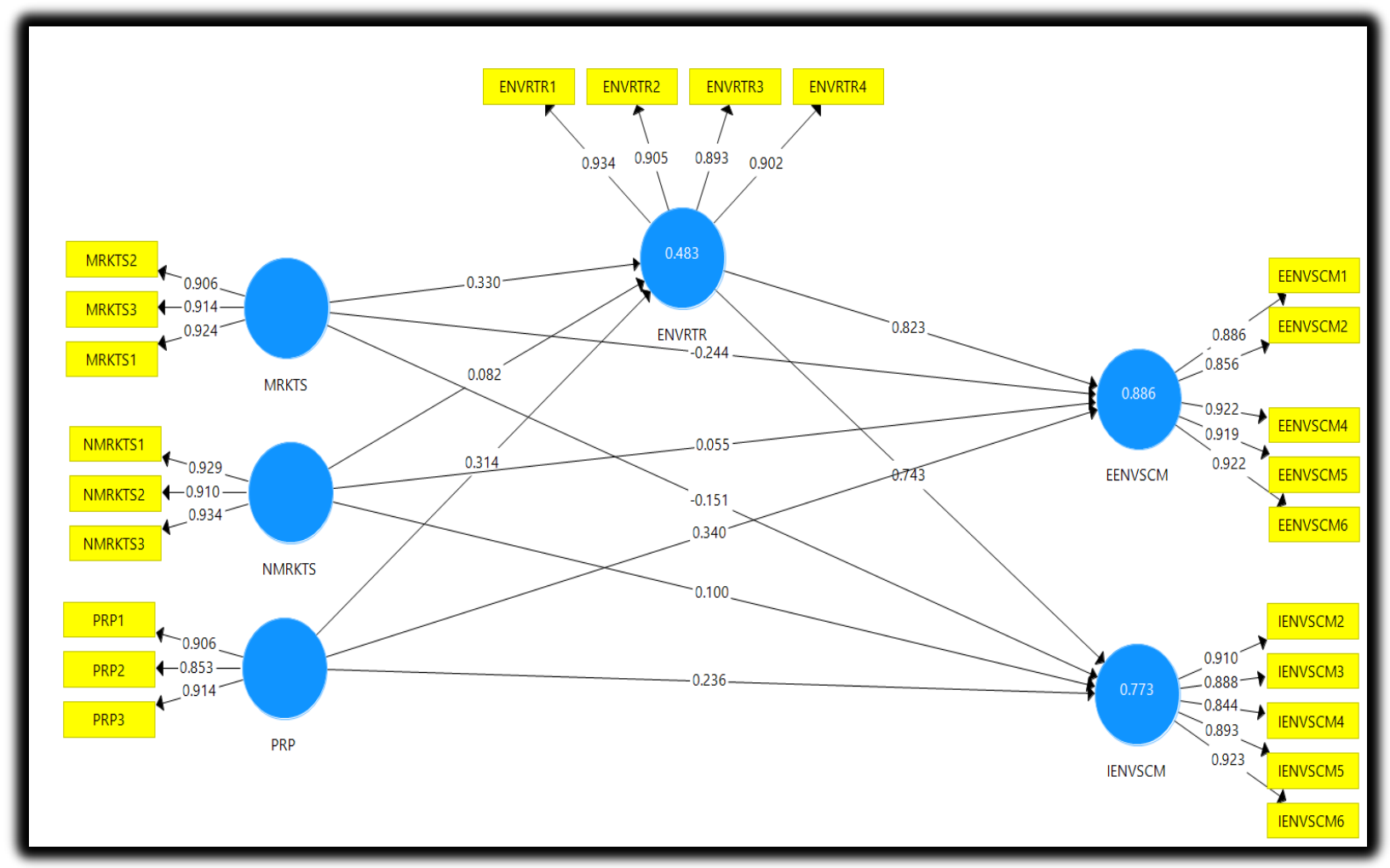

Figure 2. Measurement Model.

By evaluating the outer loadings of individual construct item reliability was measured with PLS-SEM technique. The common approach is to preserve items with loadings in the range of 0.40 and 0.70 Though, it is appropriate to keep item loadings greater or equal to 0.70 (Hair, Sarstedt, Hopkins, \& Kuppelwieser, 2014; Henseler et al., 2015). According to scholar, items loadings less than 0.50 are considered poor, between 0.61 and 0.50 are fair, moderate if it falls between 0.51 to 0.60 , while the range between 0.61 to 0.80 is termed as moderately strong and very strong if it falls between 0.81 to 1.00 . Moreover, the item loadings for the mutual relationship must be above 0.70 .

The extent at which two measures which are supposed to be related to one another also appear related after the analysis is known as Convergent validity. According to the (Hair et al, 2016) the measures which are frequently used to determine the CV are AVE, composite reliability and the factor loadings. Primarily, item loadings were analysed. The literature indicates that the acceptable value of items loading is 0.50 or more (Hair et al., 2014; Tzempelikos \& Gounaris, 2017). Table 4.5 shows that all items loadings were greater than 0.50 except for only 1 item loading. Next, the composite reliability was tested which indicate the extent of the items to reliably indicate the underlying construct (Hair et al., 2016). According to the (Hair et al. ,2016) the acceptable CR value is 0.70 Table 2 shows that the CR values for all constructs range between 0.872 and 
0.968 which is exceeding the suggested values. Among the latent variable indicators, the degree of common variance is termed as AVE. (Hair et al. ,2016) was also analysed and suggested value for AVE is greater than 0.50 . Table 2 shows the AVE values range from 0.512 to 0.834 , indicating convergent validity. CR values for the dimensions of work commitment (for the establishment of the second order construct) are also presented in Table 2.

Table 1. Outer Loadings.

\begin{tabular}{|c|c|c|c|c|c|c|}
\hline & EENVSCM & ENVRTR & IENVSCM & MRKTS & NMRKTS & PRP \\
\hline EENVSCM1 & 0.886 & & & & & \\
\hline EENVSCM2 & 0.856 & & & & & \\
\hline EENVSCM4 & 0.922 & & & & & \\
\hline EENVSCM5 & 0.919 & & & & & \\
\hline EENVSCM6 & 0.922 & & & & & \\
\hline ENVRTR1 & & 0.934 & & & & \\
\hline ENVRTR2 & & 0.905 & & & & \\
\hline ENVRTR3 & & 0.893 & & & & \\
\hline ENVRTR4 & & 0.902 & & & & \\
\hline IENVSCM2 & & & 0.910 & & & \\
\hline IENVSCM3 & & & 0.888 & & & \\
\hline IENVSCM4 & & & 0.844 & & & \\
\hline IENVSCM5 & & & 0.893 & & & \\
\hline IENVSCM6 & & & 0.923 & & & \\
\hline MRKTS2 & & & & 0.906 & & \\
\hline MRKTS3 & & & & 0.914 & & \\
\hline NMRKTS1 & & & & & 0.929 & \\
\hline NMRKTS2 & & & & & 0.910 & \\
\hline NMRKTS3 & & & & & 0.934 & \\
\hline PRP1 & & & & & & 0.906 \\
\hline PRP2 & & & & & & 0.853 \\
\hline PRP3 & & & & & & 0.914 \\
\hline MRKTS1 & & & & 0.924 & & \\
\hline
\end{tabular}

Table 2. Reliability.

\begin{tabular}{|l|l|l|l|l|}
\hline & Cronbach's Alpha & rho_A & CR & (AVE) \\
\hline EENVSCM & 0.942 & 0.943 & 0.956 & 0.812 \\
\hline ENVRTR & 0.929 & 0.929 & 0.950 & 0.825 \\
\hline IENVSCM & 0.935 & 0.937 & 0.951 & 0.795 \\
\hline MRKTS & 0.902 & 0.903 & 0.939 & 0.837 \\
\hline NMRKTS & 0.915 & 0.921 & 0.946 & 0.854 \\
\hline PRP & 0.870 & 0.873 & 0.921 & 0.795 \\
\hline
\end{tabular}

Discriminant validity seeks to confirm that after running an analysis a particular measure is not related to other measures. It ensures the CV of the outer model. According to scholar suggestions, this was done by examining square roots 151 of the AVE with correlations amongst the latent constructs. The AVE score of 0.50 and above is suggested and the square root of AVE must be more than the correlations amongst the latent constructs. 
Table 3. Discriminant Validity.

\begin{tabular}{|l|l|l|l|l|l|l|}
\hline & EENVSCM & ENVRTR & IENVSCM & MRKTS & NMRKTS & PRP \\
\hline EENVSCM & 0.901 & & & & & \\
\hline ENVRTR & 0.822 & 0.908 & & & & \\
\hline IENVSCM & 0.805 & 0.864 & 0.892 & & & \\
\hline MRKTS & 0.748 & 0.770 & 0.636 & 0.905 & & \\
\hline NMRKTS & 0.764 & 0.737 & 0.648 & 0.860 & 0.904 & \\
\hline PRP & 0.728 & 0.768 & 0.689 & 0.860 & 0.865 & 0.891 \\
\hline
\end{tabular}

After establishing the outer model, we also assess the inner model which involves hypotheses testing by calculating t-values and path coefficients. In this study we have applied a bootstrapping process with 500 samples to determine the significance of path coefficients. Who suggested that 200 to 1000 number of bootstrap samples result in sufficient standard error estimates? To determine the significance of path coefficient present study depended on bootstrapping method which is set in Smart PLS software.

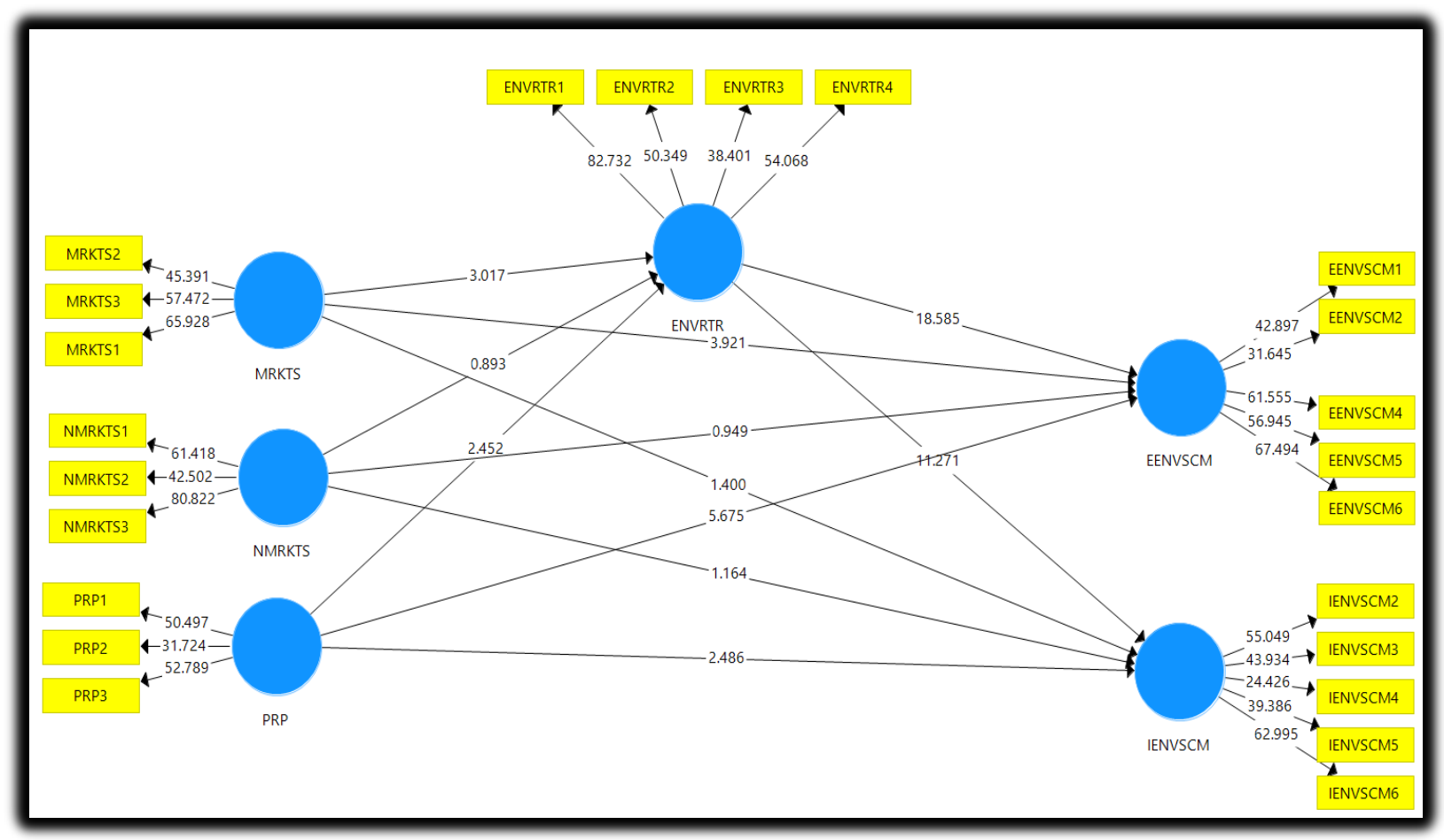

Figure 3. Structural Model.

Table 4. Direct relationship.

\begin{tabular}{|l|l|l|l|l|l|}
\hline & $(\mathbf{O})$ & $(\mathbf{M})$ & $(\mathbf{S T D E V})$ & $(|\mathbf{O} / \mathrm{STDEV}|)$ & P Values \\
\hline ENVRTR -> EENVSCM & 0.823 & 0.817 & 0.044 & 18.585 & 0.000 \\
\hline ENVRTR -> IENVSCM & 0.743 & 0.735 & 0.066 & 11.271 & 0.000 \\
\hline MRKTS -> EENVSCM & -0.244 & -0.243 & 0.062 & 3.921 & 0.000 \\
\hline MRKTS -> ENVRTR & 0.330 & 0.326 & 0.109 & 3.017 & 0.001 \\
\hline MRKTS -> IENVSCM & -0.151 & -0.150 & 0.108 & 1.400 & 0.081 \\
\hline NMRKTS -> EENVSCM & 0.055 & 0.061 & 0.058 & 0.949 & 0.171 \\
\hline
\end{tabular}




\begin{tabular}{|l|l|l|l|l|l|}
\hline NMRKTS -> ENVRTR & 0.082 & 0.090 & 0.092 & 0.893 & 0.186 \\
\hline NMRKTS -> IENVSCM & 0.100 & 0.098 & 0.086 & 1.164 & 0.122 \\
\hline PRP -> EENVSCM & 0.340 & 0.341 & 0.060 & 5.675 & 0.000 \\
\hline PRP -> ENVRTR & 0.314 & 0.311 & 0.128 & 2.452 & 0.007 \\
\hline PRP -> IENVSCM & 0.236 & 0.245 & 0.095 & 2.486 & 0.006 \\
\hline
\end{tabular}

Table 5. Mediation.

\begin{tabular}{|l|l|l|l|l|l|}
\hline & $(\mathbf{O})$ & $(\mathbf{M})$ & $($ STDEV $)$ & $(\mathbf{O} /$ STDEV $)$ & $\mathbf{P}$ \\
\hline MRKTS $>>$ ENVRTR $>$ EENVSCM & 0.271 & 0.266 & 0.089 & 3.059 & 0.001 \\
\hline NMRKTS -> ENVRTR -> EENVSCM & 0.068 & 0.074 & 0.075 & 0.896 & 0.185 \\
\hline PRP $>$ ENVRTR $>$ EENVSCM & 0.258 & 0.252 & 0.103 & 2.519 & 0.006 \\
\hline MRKTS -> ENVRTR -> IENVSCM & 0.245 & 0.238 & 0.081 & 3.027 & 0.001 \\
\hline NMRKTS -> ENVRTR -> IENVSCM & 0.061 & 0.066 & 0.068 & 0.896 & 0.185 \\
\hline PRP $>$ ENVRTR $>$ IENVSCM & 0.233 & 0.227 & 0.093 & 2.504 & 0.006 \\
\hline
\end{tabular}

I

$\mathrm{n}$ PLS-SEM for the assessing the structural model, the coefficient of determination is a pertinent condition, termed as R-squared value (Hair et al, 2017). Literature indicates that minimum acceptable level of $R 2$ value as 0.10 (Hair et al., 2016). The $R 2$ values of 0.19 considered as small, 0.33 medium, and 0.67 large. In this research, the $\mathrm{R} 2$ values of the criterion variable (work commitment) fulfil the criteria as presented in Table 6.

Table 6. R-square.

\begin{tabular}{|l|l|}
\hline & R Square \\
\hline EENVSCM & 0.886 \\
\hline ENVRTR & 0.483 \\
\hline IENVSCM & 0.773 \\
\hline
\end{tabular}

Furthermore, we have also measured, the predictive relevance of the model for the assessment of model's quality as per (Hair et al. ,2016). In Smart PLS software blindfolding is used for the estimation of predictive relevance. In blindfolding technique, few cases are omitted and manipulated as missing values for the estimation of parameters (Hair et al., 2014).

Table 7. Q-square.

\begin{tabular}{|l|l|l|l|}
\hline & SSO & SSE & $\mathbf{Q}^{2}(=1-S S E / S S O)$ \\
\hline EENVSCM & $1,085.000$ & 345.680 & 0.681 \\
\hline ENVRTR & 868.000 & 543.653 & 0.374 \\
\hline IENVSCM & $1,085.000$ & 457.266 & 0.579 \\
\hline
\end{tabular}




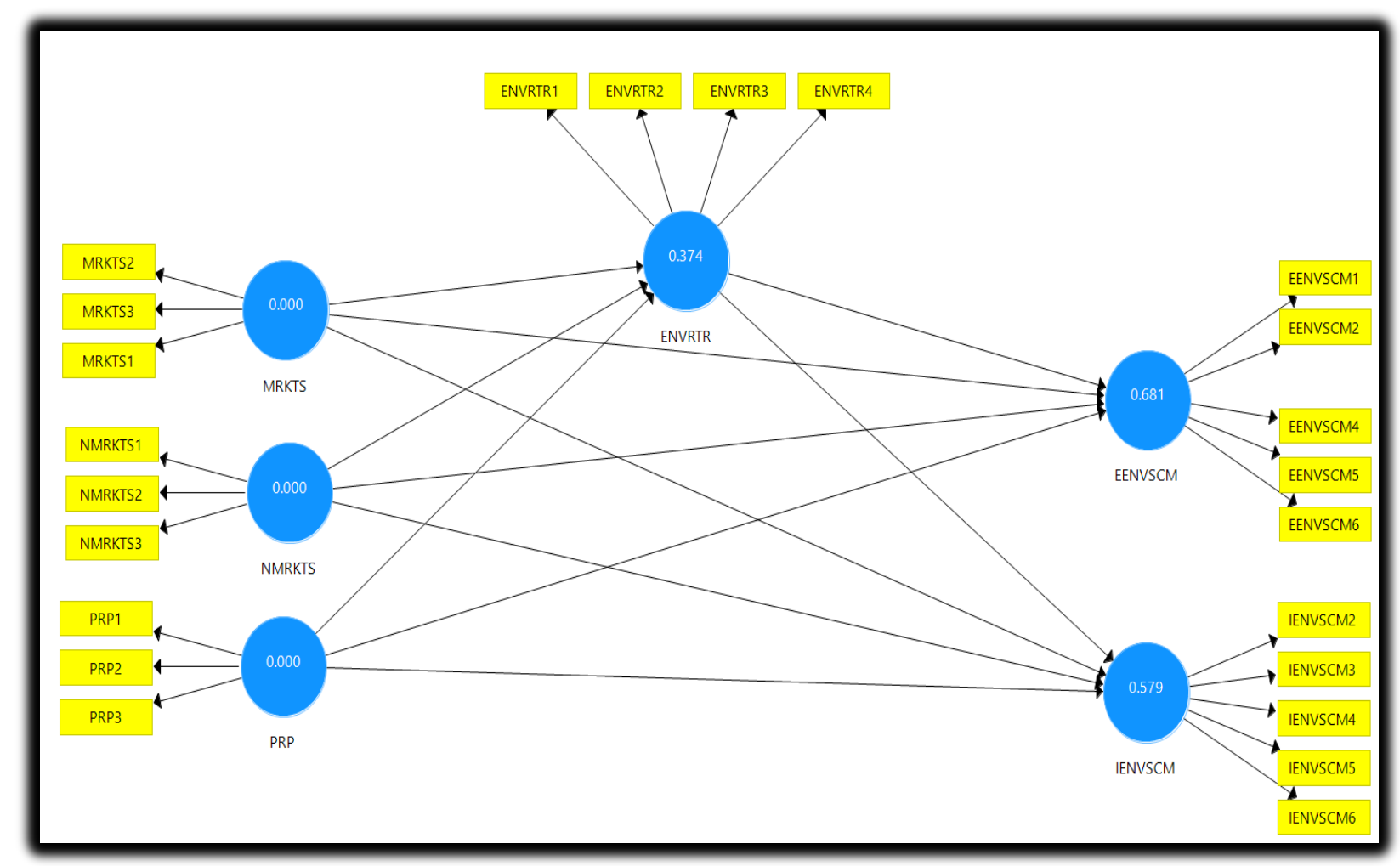

Figure 4. Q-square.

\section{CONCLUSION}

This study aims to analyse stakeholders' pressures and the role of environmental training as a mediator. The mediation analysis indicates a partial mediating role of environmental training in the relationship of regulatory stakeholders and market with the adoption of GSCM practices. Two important findings are obtained in this study; firstly, regulatory governance and MRKTS are of significant importance for implementing ESCM practices. Secondly, greater ESCM initiatives will be achieved by the use of environmental training, as compared to the case of separately using stakeholder governance mechanism as pressure for the firm. Findings also suggested that regulatory governance itself has an important role but combining it with market stakeholder may help firms to achieve effectiveness of sustainability enhancing initiatives (Epstein, 2018). Successful handling of stakeholder pressures leads to greater learning, which eventually enable firms to consider implementing social issues in their supply chains and then evaluate how they influence social performance. In addition, manufacturers can handle a firm's environmental operations through adopting effective governance mechanism (Loomis \& Paterson, 2018). It is further revealed in the mediation analysis of this study that market stakeholder pressure is found to be highly relevant as well as interrelated. Hence, regulatory stakeholder pressure and market pressure are the main contributors or drivers for the manufacturers to implement ESCM practices. When there is low stakeholder pressure, environmental training programs may seem less helpful to capture the real nature of these programs particularly in South Asian economies. The findings suggest that for environmental training programs, more attention should be given towards managing the coordination quality in order to successfully improve the adoption of ESCM practices. Thus summarizing, the notion that market stakeholder is the main contributor of ESCM practices adoption and the relationship of stakeholder pressure and ESCM practices adoption is mediated by firm's 
environmental training programs is supported by the study findings (Yawar \& Seuring, 2017). Finally, findings also suggest that adopting ESCM practices depends entirely on the firm's resources and is further enhanced by regulatory stakeholders and market pressures. This study also has some limitations. The data for this research was only taken from the firm side, therefore, in future studies, firms and stakeholders' data can also be considered and collected for revealing those potential areas that need immediate actions and attention for enhancing sustainability. Keeping in view the essential role of environmental training programs, there is also a need to assess if these training programs play the role of mediator under different geographic and regulatory conditions and in other industries. In addition, no supportive evidence is obtained in favour of NMRKTS. The active role of non-market stakeholder in sustainability initiatives can also be examined in future studies. For international buyers, a key managerial implication is that the implementation of sustainability practices in firms is not likely to be fully implemented. Therefore, in Southeast Asia, stakeholder pressure is the main driving force to implement these environmental practices. However, for the effective adoption of environmental initiatives, managers can integrate environmental training programs. From a practical point of view, environmental training programs can be adopted to further improve the implementation of ESCM practices, moreover, in South Asia, it also serves as a primary governance mechanism for the international buyers.

\section{REFERENCES}

Bansal, P., \& Song, H.-C. (2017). Similar but not the same: Differentiating corporate sustainability from corporate responsibility. Academy of Management Annals, 11(1), 105-149. https://doi.org/10.5465/annals.2015.0095

Betts, T. K., Wiengarten, F., \& Tadisina, S. K. (2015). Exploring the impact of stakeholder pressure on environmental management strategies at the plant level: what does industry have to do with it? Journal of Cleaner Production, 92, 282-294. https://doi.org/10.1016/i.jclepro.2015.01.002

Bratton, J., \& Gold, J. (2017). Human resource management: theory and practice: Palgrave.

Chin, T. A., Tat, H. H., \& Sulaiman, Z. (2015). Green supply chain management, environmental collaboration and sustainability performance. Procedia Cirp, 26, 695-699. https://doi.org/10.1016/i.procir.2014.07.035

Dikko, M. (2016). Establishing construct validity and reliability: Pilot testing of a qualitative interview for research in Takaful (Islamic insurance). The Qualitative Report, 21(3), 521-528.

Epstein, M. J. (2018). Making sustainability work: Best practices in managing and measuring corporate social, environmental and economic impacts: Routledge. https://doi.org/10.4324/9781351280129-3

Esmaeilian, B., Behdad, S., \& Wang, B. (2016). The evolution and future of manufacturing: A review. Journal of Manufacturing Systems, 39, 79-100. https://doi.org/10.1016/i.jmsy.2016.03.001

Govindan, K., Soleimani, H., \& Kannan, D. (2015). Reverse logistics and closed-loop supply chain: A comprehensive review to explore the future. European Journal of Operational Research, 240(3), 603626. https://doi.org/10.1016/i.ejor.2014.07.012

Gupta, H., \& Barua, M. K. (2017). Supplier selection among SMEs on the basis of their green innovation ability using BWM and fuzzy TOPSIS. Journal of Cleaner Production, 152, 242-258. https://doi.org/10.1016/j.jclepro.2017.03.125

Hair, Hult, G. T. M., Ringle, C., \& Sarstedt, M. (2016). A primer on partial least squares structural equation modeling (PLS-SEM): Sage publications. https://doi.org/10.3926/oss.37

Hair, Hult, G. T. M., Ringle, C. M., \& Thiele, K. O. (2017). Mirror, mirror on the wall: a comparative evaluation of composite-based structural equation modeling methods. Journal of the Academy of Marketing Science, 45(5), 616-632. https://doi.org/10.1007/s11747-017-0517-x 
Hair, Sarstedt, M., Hopkins, L., \& Kuppelwieser, V. (2014). Partial least squares structural equation modeling (PLS-SEM) An emerging tool in business research. European Business Review, 26(2), 106-121. https://doi.org/10.1108/ebr-10-2013-0128

Henseler, J., Ringle, C. M., \& Sarstedt, M. (2015). A new criterion for assessing discriminant validity in variance-based structural equation modeling. Journal of the Academy of Marketing Science, 43(1), 115-135. https://doi.org/10.1007/s11747-014-0403-8

Hojnik, J., \& Ruzzier, M. (2016). What drives eco-innovation? A review of an emerging literature. Environmental Innovation and Societal Transitions, 19, 31-41. https://doi.org/10.1016/j.eist.2015.09.006

Jabbour, C. J. C., \& Jabbour, A. B. L. (2016). Green human resource management and green supply chain management: Linking two emerging agendas. Journal of Cleaner Production, 112, 1824-1833. https://doi.org/10.1016/j.jclepro.2015.01.052

Janadari, M., Sri Ramalu, S., \& Wei, C. (2016). Evaluation of measurment and structural model of the reflective model constructs in PLS-SEM.

Jermsittiparsert, K., Namdej, P., \& Sriyakul, T. (2019). Impact of Quality Management Techniques and System Effectiveness on the Green Supply Chain Management Practices. International Journal of Supply Chain Management, 8(3), 120-130. https://doi.org/10.1115/1.860281_ch4

Jermsittiparsert, K., Siriattakul, P., \& Sangperm, N. (2019). Predictors of Environmental Performance: Mediating Role of Green Supply Chain Management Practices. International Journal of Supply Chain Management, 8(3), 877-888.

Juntunen, J. K., Halme, M., \& Korsunova, A. R., Risto. (2019). Strategies for integrating stakeholders into sustainability innovation: a configurational perspective. Journal of Product Innovation Management, 36(3), 331-355. https://doi.org/10.1111/jpim.12481

Liang, D., \& Liu, T. (2017). Does environmental management capability of Chinese industrial firms improve the contribution of corporate environmental performance to economic performance? Evidence from 2010 to 2015. Journal of Cleaner Production, 142, 2985-2998. https://doi.org/10.1016/j.jclepro.2016.10.169

Loomis, D. K., \& Paterson, S. (2018). A comparison of data collection methods: Mail versus online surveys. Journal of Leisure Research, 49(2), 133-149. https://doi.org/10.1080/00222216.2018.1494418

Martens, M. L., \& Carvalho, M. M. (2017). Key factors of sustainability in project management context: A survey exploring the project managers' perspective. International Journal of Project Management, 35(6), 1084-1102. https://doi.org/10.1016/j.ijproman.2016.04.004

Meixell, M. J., \& Luoma, P. (2015). Stakeholder pressure in sustainable supply chain management: a systematic review. International Journal of Physical Distribution \& Logistics Management, 45(1/2), 69-89. https://doi.org/10.1108/ijpdlm-05-2013-0155

Miles, S. (2017). Stakeholder theory classification: A theoretical and empirical evaluation of definitions. Journal of Business Ethics, 142(3), 437-459. https://doi.org/10.1007/s10551-015-2741-y

Mitra, S., \& Datta, P. P. (2014). Adoption of green supply chain management practices and their impact on performance: an exploratory study of Indian manufacturing firms. International Journal of Production Research, 52(7), 2085-2107. https://doi.org/10.1080/00207543.2013.849014

Mohanty, R., \& Prakash, A. (2014). Green supply chain management practices in India: an empirical $\begin{array}{llll}\text { study. Production Planning \& Control, } & 25(16), & \text { 1322-1337. }\end{array}$ https://doi.org/10.1080/09537287.2013.832822

Odeyale, S. O., Oguntola, A. J., \& Odeyale, E. O. (2014). Evaluation and selection of an effective green supply chain management strategy: A case study. International Journal of Research Studies in Management, 3(1), 27-39. https://doi.org/10.5861/ijrsm.2013.550 
Oraedu, C. (2019). Structural Equation Test of Service Quality Dimensions on the Relationship Quality Construct: Evidence from an Emerging Telecom Market. Journal of Relationship Marketing, 18(2), 146-171. https://doi.org/10.1080/15332667.2018.1534066

Paauwe, J., \& Boon, C. (2018). Strategic HRM: A critical review Human Resource Management (pp. 4973): Routledge. https://doi.org/10.4324/9781315299556-3

Sarstedt, M., \& Cheah, J.-H. (2019). Partial least squares structural equation modeling using SmartPLS: a software review. Journal of Marketing Analytics, 1-7. https://doi.org/10.1057/s41270-019-00058-3

Stead, J. G., \& Stead, W. E. (2017). Management for a small planet: Routledge.

Tachizawa, E. M., \& Wong, C. Y. (2015). The performance of green supply chain management governance mechanisms: A supply network and complexity perspective. Journal of Supply Chain Management, 51(3), 18-32. https://doi.org/10.1111/jscm.12072

Tantalo, C., \& Priem, R. L. (2016). Value creation through stakeholder synergy. Strategic Management Journal, 37(2), 314-329. https://doi.org/10.1002/smj.2337

Tzempelikos, N., \& Gounaris, S. (2017). A conceptual and empirical examination of key account management orientation and its implications-the role of trust The Customer is NOT Always Right? Marketing Orientationsin a Dynamic Business World (pp. 673-681): Springer. https://doi.org/10.1007/978-3-319-50008-9_185

Wolf, J. (2014). The relationship between sustainable supply chain management, stakeholder pressure and corporate sustainability performance. Journal of Business Ethics, 119(3), 317-328. https://doi.org/10.1007/s10551-012-1603-0

Wong. (2016). Mediation analysis, categorical moderation analysis, and higher-order constructs modeling in Partial Least Squares Structural Equation Modeling (PLS-SEM): A B2B Example using SmartPLS. Marketing Bulletin, 26.

Wong, Wong, C. W., \& Boon-Itt, S. (2015). Integrating environmental management into supply chains: a systematic literature review and theoretical framework. International Journal of Physical Distribution \& Logistics Management, 45(1/2), 43-68. https://doi.org/10.1108/ijpdlm-05-2013-0110

Wong, Wong, C. Y., \& Boon-itt, S. (2018). How does sustainable development of supply chains make firms lean, green and profitable? A resource orchestration perspective. Business Strategy and the Environment, 27(3), 375-388. https://doi.org/10.1002/bse.2004

Wright, C., \& Nyberg, D. (2017). An inconvenient truth: How organizations translate climate change into business as usual. Academy of Management Journal, 60(5), 1633-1661. https://doi.org/10.5465/amj.2015.0718

Yawar, S. A., \& Seuring, S. (2017). Management of social issues in supply chains: a literature review exploring social issues, actions and performance outcomes. Journal of Business Ethics, 141(3), 621643. https://doi.org/10.1007/s10551-015-2719-9

Zhao, X., \& Sun, B. (2016). The influence of Chinese environmental regulation on corporation innovation and competitiveness. Journal of Cleaner Production, 112, 1528-1536. https://doi.org/10.1016/j.jclepro.2015.05.029

\section{(2) $\odot \Theta \Theta$}

This work is licensed under a Attribution-NonCommercial-NoDerivatives 4.0 International (CC BY-NC-ND 4.0). 